\title{
The Effect of Intellectual Capital on Organizational Performance: The Mediating Role of Knowledge Sharing
}

\author{
Bader Yousef Obeidat', Ayman Bahjat Abdallah1, Noor Osama Aqqad1, \\ Abdel Hakeem Oqlah M. Akhoershiedah², Mahmoud Maqableh ${ }^{3}$ \\ ${ }^{1}$ Department of Business Management, School of Business, The University of Jordan, Amman, Jordan \\ ${ }^{2}$ Department of Public Administration, School of Business, The University of Jordan, Amman, Jordan \\ ${ }^{3}$ Management Information Systems, School of Business, The University of Jordan, Amman, Jordan \\ Email: b.obeidat@ju.edu.jo, a.abdallah@ju.edu.jo,nooraqqad1202@gmail.com,maqableh@ju.edu.jo
}

How to cite this paper: Obeidat, B.Y., Abdallah, A.B., Aqqad, N.O., Akhoershiedah, A.H.O.M. and Maqableh, M. (2017) The Effect of Intellectual Capital on Organizational Performance: The Mediating Role of Knowledge Sharing. Communications and Network, 9, 1-27.

https://doi.org/10.4236/cn.2017.91001

Received: October 20, 2016

Accepted: December 4, 2016

Published: December 7, 2016

Copyright $\odot 2017$ by authors and Scientific Research Publishing Inc. This work is licensed under the Creative Commons Attribution International License (CC BY 4.0).

http://creativecommons.org/licenses/by/4.0/

\begin{abstract}
Understanding the various effects that exist among intellectual capital, knowledge sharing, and organizational performance is the main purpose of this study. Data were gathered from 356 employees working in manufacturing companies in Jordan. In order to test the hypotheses of this study, the approach suggested by [1] was undertaken. The results of the analysis revealed that intellectual capital had a positive effect on organizational performance and knowledge sharing. The results also showed that knowledge sharing had a positive effect on organizational performance. Finally, it was found that knowledge sharing had a positive mediating effect on the relationship between intellectual capital and organizational performance. The findings of this study thus provide many benefits for researchers and practitioners despite the presence of some limitations.
\end{abstract}

\section{Keywords}

Intellectual Capital, Knowledge Sharing, Organizational Performance

\section{Introduction}

Organizations today face the need to change their policies and strategies [2] in response to social developments and demographic changes such as globalization, increasing competition, technological advancements, and the rapid aging of the population [3]-[8]. Therefore, traditional organizational management is not considered the most appropriate strategy and organizations need to think of other ways to compete in the market [9]. Given these dramatic changes, organi- 
zations nowadays have concentrated on investing in such areas as employee training, customer relations, research and development, and computer systems [10], in addition to knowledge resources and their use [11]. These investments, also known as intellectual capital, are taking over the need to invest in the physical and financial capital of the firm [12]. In addition, [13] stated that organizations have shifted their attention to intellectual capital instead of the traditional physical and financial capital as a basis for competition. This is due to the fact that intellectual capital is being recognized as the foundation for success in today's knowledge economy [14]. Although organizations have avoided the area of intellectual capital for many years [15], scholars have come to emphasize the apparent importance of measuring and managing intellectual capital [16]. Managers, investors, policymakers and others have focused increasingly on IC, seeing it a key resource in business [17]. This is because intellectual capital has been reported to influence organizations in areas of significant importance to their survival such as economic growth [18], value creation [19] [20], competitiveness [21], business performance [22], job performance [23] and sustainability [24]. Intellectual capital is also important as it shows that organizations characterized by skilled, creative, and distinctive knowledgeable employees, supportive organizational structures and systems, and maintain cordial customer relations contribute to achieving superior organizational positions [25] [26].

Another important resource for organizations is knowledge [27] [28] [29] [30]. [31] stated that knowledge is the blood that runs through the organization's veins and is an important element for the survival of the organization in today's dynamic and competitive environment. According to [32], knowledge helps organizations sustain and maintain a competitive advantage and therefore organizations need to have policies and infrastructures to effectively manage knowledge. In order to have successful knowledge management organizations need to have a well-functioning human resource management and facilitating employees' behavior toward knowledge creating, knowledge sharing, and the application of knowledge [33] [34]. According to [35], knowledge management practices that enhance intermediate organizational performance will lead to positive financial performance. Of these knowledge management practices knowledge sharing can be seen as valuable for organizations as it helps them improve efficiency or performance [36] [37] [38] [39]. Knowledge sharing refers to the "collective beliefs or behavioral routines related to the spread of learning among different individuals or units within an organization” ([40], p. 38). Knowledge sharing is of importance for organizations for many reasons. [41] stated that the innovation ability of organizations can be enhanced by knowledge sharing which facilitates the ability to achieve organizational goals. In addition, [42] suggested that businesses can gain a competitive advantage through knowledge sharing as it creates the opportunity to meet organizational needs and generates solutions and efficiencies. Furthermore, knowledge sharing provides the link between individual knowledge and organizational knowledge [43] and helps individuals develop their skills and knowledge which makes their job easier and saves them 
time to perform more substantive tasks [44] [45].

Furthermore, the performance of organizations is considered an important issue for all organizations-profit or non-profit [46] [47]. Although organizational performance is a focal point in business studies, it is a complex and multidimensional phenomenon to study [40] as it is anchored around stakeholders, heterogeneous market conditions, and time [48]. Organizational performance refers to the ability of organizations to meet its stakeholders' needs and its own needs for survival [49]. Organizations differ in performance due to the variance in organizational resources which include tangible and intangible resources [50]. Therefore, improving organizational performance is not solely dependent on the successful deployment of tangible resources but also on intangible resources such as the effective management of knowledge [51] and the behavior of employees [52]. This is supported by [53] who stated that the smart management of all human resources who represent the knowledge capital of organizations and the capability to generate, acquire, store, transfer, and apply knowledge will help support organizational goals and objectives.

The objective of the current study is to investigate the effect of intellectual capital on knowledge sharing and organizational performance of manufacturing companies in Jordan. Furthermore, the effect of knowledge sharing on organizational performance is investigated. Additionally, the mediating effect of knowledge sharing on the relationship between intellectual capital and organizational performance is explored. To the best of the authors' knowledge, no empirical studies have been conducted in Jordan to investigate the proposed relationships. Moreover, the study derives its importance of being conducted in the Jordanian manufacturing sector which is seriously suffering from the severe global competition, and needs to capture and exploit all possible opportunities to enhance organizational performance.

\subsection{Intellectual Capital (IC)}

Intellectual capital has become a topic of great interest as a result of the introduction of the new economy [54]. According to [55], this so called new economy, also known as the knowledge economy, has shifted attention to the intangible assets possessed by organizations and how they are managed. This is supported by [56] who stated that for organizations operating in this new economy, intellectual not physical capital is considered to be an organization's most prized asset. The reason why intellectual capital is considered valuable relates to the fact that intangible assets are more important than tangible assets [57]. Furthermore, [58] mentioned that in order for these organizations to remain competitive a systematic approach to intellectual capital must be undertaken.

The concept of intellectual capital has changed considerably over time. At first, IC was introduced as the difference between the book value and market value of an organization [59]. Later on, ([60], p. 358) referred to IC as "knowledge that can be converted into value". [61] suggested that IC is the capability of creating value when faced with constant change. In addition, [62] defined IC as 
the sum of all knowledge used in business operations to gain a competitive advantage. However, the most common definition of intellectual capital must be the one provided by ([63], p. 5) who referred to it as "the possession of knowledge and experience, professional knowledge and skill, goal relationships, and technological capabilities which when applied will give organizations competitive advantage". As a result, it can be concluded that intellectual capital is made up of resources and capabilities that rare, inimitable, valuable, and non-substitutable which all lead to companies having superior performance and a lasting competitive advantage [64].

Literature provides many frameworks for measuring intellectual capital. According to [60], IC is comprised of four components; human, customer, process, and innovation. [65] suggested that IC is mainly divided into individual competence, internal structure, and external structure. However, it can be seen that the most accepted framework of IC consists of three components which are: human capital (human resources), structural capital (organizational values), and relational capital (relationships) (see [66] [67] [68] [69]). Furthermore, [13] mentioned that these three IC dimensions are interrelated and hence have a significant influence on a firm's value position and performance. This is supported by [70] who mentioned that intellectual capital must include human capital, structural capital, and relational capital for organizations to achieve their goals as they are interdependent and intertwined with each other. For the purposes of this paper the IC dimensions of human capital, structural capital, and relational capital will be used in accordance with the study of [71].

\subsubsection{Human Capital (HC)}

One of the most important resources organizations rely on is human capital as it helps organizations respond to environmental changes innovatively [72]. In addition, human capital is considered to be of vital importance as it affects the performance of organizations [73]. Furthermore, [74] mentioned that the importance of human capital lies in its ability to improve the efficacy and efficiency of organizations and in turn gain a competitive advantage. Therefore, human capital is considered to be the most significant intellectual capital component as the existence of the firm relies on it [75].

Human Capital (HC) can be defined as "the sum of employees' competence, knowledge, skills, innovativeness, attitude, commitment, wisdom and experience" ([76], p. 234). Human capital is consists of the values, attitudes, and habits of the people in the organization, in addition to the leadership that motivates people to display their potential in the organization [77]. It must be noted that the human capital of one organization is different from that of another which gives the characteristics of being inimitable, rare and non-replaceable [70]. In addition, [78] and [79] reported that human capital is not fully controlled by the firm which distinguishes it from the other resources available in the firm. As a result, [57] advised that organizations should continuously invest in their human capital in order to improve their competitive advantage. 


\subsubsection{Structural Capital (SC)}

Structural capital deals with the mechanisms and structures of the organization which ultimately influences organizational innovation thereby making it an important organizational resource [72]. Moreover, [73] reported that structural capital is used to retain the human capital of organizations. This is due to the fact that structural capital acts as a supportive infrastructure for $\mathrm{HC}$ a set provides the necessary environment for individuals to invest their human capital and knowledge [70]. According to [80], structural capital (SC) refers to organizational capabilities that are used to meet internal and external challenges. Structural capital can also be defined as the non-human storehouses of knowledge such as organizational culture, routines, data bases, information systems, patents, copyrights, trademarks and so on (see [15] [75] [76]). [81] referred to structural capital as the knowledge that is created and owned by an organization. Unlike human capital, structural capital is owned by the firm [79], and as a result can be traded, reproduced and shared within the firm [82]. Therefore, SC is considered the dimension that allows IC to be measured and developed in an organization [83].

\subsubsection{Relational Capital (RC)}

The premise of relational capital revolves around connecting internal intellectual resources with external stakeholders, hence influencing an organization's ability to create value [76]. According to ([84], p. 517), relational capital (RC) can be defined as "the knowledge that is embedded in the relationships with any stakeholder that affects the firm's life". [85] reported that relational capital benefits both the organization and its members equally as they both own it. Furthermore, [74] mentioned that relational capital is extremely important in order to actualize the wealth-creation potential of human and structural capital. Therefore, [81] reported that creating and maintain relational capital is crucial for having successful organizations.

\subsection{Knowledge Sharing}

Organizations operate in an environment characterized by uncertainty, change, and instability that lead to the creation of various challenges [86]. In addition, many trends have emerged as a result of globalization which requires organizations to quickly and easily adapt to them in order to survive [87]. Given that the current age is referred to as the intellectual age, the intellectual and intangible capital known as knowledge is considered to be a key factor to organizations [88]. This is due to the fact that knowledge leads to the strengthening of a firm's core competencies and provides the necessary resources for organizations to innovate and compete [89]. Therefore, organizations that wish to survive in a dynamic and competitive environment should focus on the concept of knowledge [90] [91] [92]. This is supported by [93] [94] who mentioned that creating knowledge, sharing that knowledge across organizational entities, and embodying that knowledge in new technologies and products is necessary for organizations to be competitive. 
In addition, [95] stated that the success of organizations is highly dependent on knowledge and knowledge management. As a result, based on the previous literature the importance of knowledge for organizations can be highly noted. Knowledge can be defined as the insights, interpretations, context, experience and wisdom that help an organization to achieve its goals, mission, and vision and ultimately enhance its value [96]. Knowledge has two types; explicit and implicit knowledge [97]. Explicit knowledge refers to knowledge that can be clearly expressed; whereas implicit knowledge refers to knowledge that is difficult to convey to others as it is highly personalized ([98], p. 233). Knowledge management can be defined as the activities of capturing, using, and sharing of knowledge using various methods, systems, and practices by an organization [99]. As can be seen knowledge sharing is a component of knowledge management and is the most important behavior related to knowledge that has a direct effect on other knowledge behaviors such as knowledge integration and creation [100].

Knowledge sharing refers to the voluntary behavior by individuals to provide access to others to their own knowledge and experiences ([101] [102], p. 2) referred to knowledge sharing as "the process by which explicit or tacit knowledge can flow between individuals, or utilize from others as groups, departments, or organizations". Knowledge sharing can also be defined as the activities that lead to the transfer and dissemination of knowledge between individuals, groups, or organizations [103]. Knowledge sharing takes place between two individuals one that possesses knowledge and the other acquires knowledge [95]. This process includes the sharing of information, ideas, suggestions, and experiences related to an organization [104]. Furthermore, according to [105], organizations identify knowledge sharing as an important issue for several reasons such as; the growing importance of the value of knowledge and the increasing recognition that tacit knowledge is more valuable than explicit knowledge. In addition, [106] mentioned that difficult issues can be addressed through information sharing as many organizations are resource poor but information rich. However, sharing knowledge is not an easy process due to the fact that knowledge is created and stored within the employees of an organization [45] [107], and that it requires the willingness to collaborate and share knowledge with others [108] [109]. Unwillingness to share information can lead to the sharing of inaccurate, incomplete, and false information [108] which is disastrous to organizations.

The sharing of knowledge among employees creates many benefits for an organization which include; allowing the organization to build on previous knowledge and experiences, responding to problems more quickly, developing new ideas, fostering innovation, understanding customer needs, and building competencies [101] [110]. Literature mentioned that knowledge sharing can have different forms or processes. For example [111] differentiated between two forms of knowledge sharing which include donating and receiving information. In addition, [112] differentiated knowledge sharing on the basis of the knowledge source and the knowledge receiver. Furthermore, [113] distinguished between the knowledge carrier and the knowledge requester in knowledge sharing. In this 
paper knowledge sharing will be measured using the knowledge sharing processes of knowledge collecting and knowledge donating as suggested by [28].

\section{Knowledge Donating and Knowledge Collecting}

According to [28], knowledge sharing refers to a process where knowledge (both tacit and explicit) is mutually exchanged in order to create new knowledge. This implies that sharing "consists of both bringing (donating) knowledge and getting (collecting) knowledge" ([114], p. 116). In addition, [37] mentioned that knowledge sharing is the process that involves the acquisition (collecting) and provision (donating) of knowledge between two or more participants. Therefore, it can be concluded that knowledge sharing consists of the processes of knowledge donating and knowledge collecting as suggested by [28].

Knowledge donating can be defined as "communication based upon an individual's own wish to transfer intellectual capital" and knowledge collecting as "attempting to persuade others to share what they know" ([115], p. 126). According to [42], knowledge donating refers to the willingness to actively communicate with others and knowledge collecting as actively consulting others in order to learn from them. Based on that the processes of knowledge donating and knowledge collecting can be regarded as active processes as one is either engaged in active communication to share knowledge or actively consulting others to gain access to their knowledge [116]. [117] stated that employees who willingly engage in the process of knowledge donating are more likely to be recognized for their efforts and intellectual capital and in turn makes the process of knowledge collecting easier for their managers. Furthermore, engaging in the process of knowledge donating can be very important for organizations as it can improve the knowledge stock of an organization by transforming individual knowledge into group and organizational knowledge over time [118].

\subsection{Organizational Performance (OP)}

Organizational performance is considered an important issue for both profit and non-profit organizations [46]. Improving firm performance is something that most organizations strive to achieve [119]. Some of the factors reported in literature to have an influence on organizational performance and its improvement include: organizational culture [120], organization's environment and strategy [121], individual and organizational learning [122], and employee involvement and commitment to organizational goals [123]. Literature provides many definitions for organizational performance. According to [40], performance refers to the ability of an organization to create outcomes and actions at an acceptable level. In addition, [49] mentioned that organizational performance refers to the degree that an organization meets its own needs and its stakeholder needs in order to survive. Furthermore, [41] referred to organizational performance as a measure of how well an organization achieves its objectives. Measuring organizational performance can be performed using various objectives and measurements [46]. However, performing this task is not easy when it comes to measuring organizational performance depending solely on financial measures is in- 
sufficient, non-financial measures should be used as well [124]. [35] suggested measuring organizational performance using five dimensions that include: innovation, rate of new product development, customer satisfaction, customer retention, and operating costs. On the other hand, [56] proposes four dimensions for measuring organizational performance these include: return on assets, return on equity, revenue growth, and employee productivity. This paper uses the dimensions of operational performance and financial performance as proposed by [76].

\subsubsection{Operational Performance}

In today's environment organizations must strive to operate in the most efficient and effective manner possible [125]. This is because organizations need to face the changes brought about by these environments which are extremely dynamic and unstable [126]. Operational performance refers to "the performance related to organizations' internal operation, such as productivity, product quality and customer satisfactions" ([127], p. 26). In addition, [128] referred to operational performance as the ability to measure the outcomes of an organization's processes. Furthermore, operational performance can be defined as the non-economic aspects of an organization's social and societal relationships and competitive success factors that influence the efficiency of its operations [129]. According to [130], operational performance is usually measured using five dimensions: cost, quality, delivery, flexibility, and innovation. The reason why these non-financial measures are so popular is that they are used as a means for transferring a firm's strategy and vision into a tool that influences performance and leads to superior financial performance [131].

\subsubsection{Financial Performance}

Financial performance is the most widely used measure of organizational performance as the benefits of organizational performance usually appear in the financial results of an organization [132]. Financial performance can be defined as "the extent to which the organization performs in relative profitability, return on investment, and total sales growth" ([41], p. 120). In addition, [129] referred to financial performance as the fulfillment of an organization's economic goals which is reflected in the outcomes of financial and market indicators. [133] suggested that financial performance is usually measured using the following: return on assets (ROA), return on equity (ROE), return on investment (ROI), profit margin, earning per share, and value per employee. However, [134] reported that ROA and ROE are considered to be the most popular means for measuring a firm's financial performance. It must be noted that focusing solely on financial performance as a measure of organizational performance is not enough to improve financial results [121]. [135] mentioned that financial performance is a result of operational performance; therefore without operational performance financial performance would not exist. As a result, organizations must adopt a performance-evaluating system that looks beyond measuring only financial performance [132]. 


\section{Framework and Research Hypotheses}

\subsection{Research Framework}

Based on the literature review above, the research model was developed and its framework is depicted in Figure 1 below.

\subsection{Hypotheses Development}

Based on the research framework, intellectual capital dimensions were segmented into human capital, structural capital and relational capital. Knowledge sharing was segmented into knowledge donating and knowledge collecting. Finally, organizational performance was segmented into operational performance and financial performance. In the subsequent analysis, overall constructs of intellectual capital, knowledge sharing and organizational performance will be used.

\subsubsection{Intellectual Capital and Organizational Performance}

According to [66], it can be concluded that regardless of the industry in which an organization operates, intellectual capital does have a significant relationship with firm performance. [136] conducted a study to examine the relationship between intellectual capital and firm performance in terms of profitability and productivity. Results showed that intellectual capital has a significant relationship with productivity but no relationship with profitability. In addition, [12] research conducted on 300 UK companies showed that there is a significant positive relationship between intellectual capital and a firm's financial performance. A study conducted by [124] revealed that intellectual capital has a significant impact on organizational performance. Furthermore, [137] indicated that intellectual capital influences firm performance in a positive manner. However, [138] found that human capital has a significant negative relationship with firm performance. Moreover, [139] pointed out that there is no relationship between intellectual capital and firm performance.

H1. Intellectual capital positively affects organizational performance.

\subsubsection{Intellectual Capital and Knowledge Sharing}

[140] suggested that intellectual capital can influence and individual's motivation

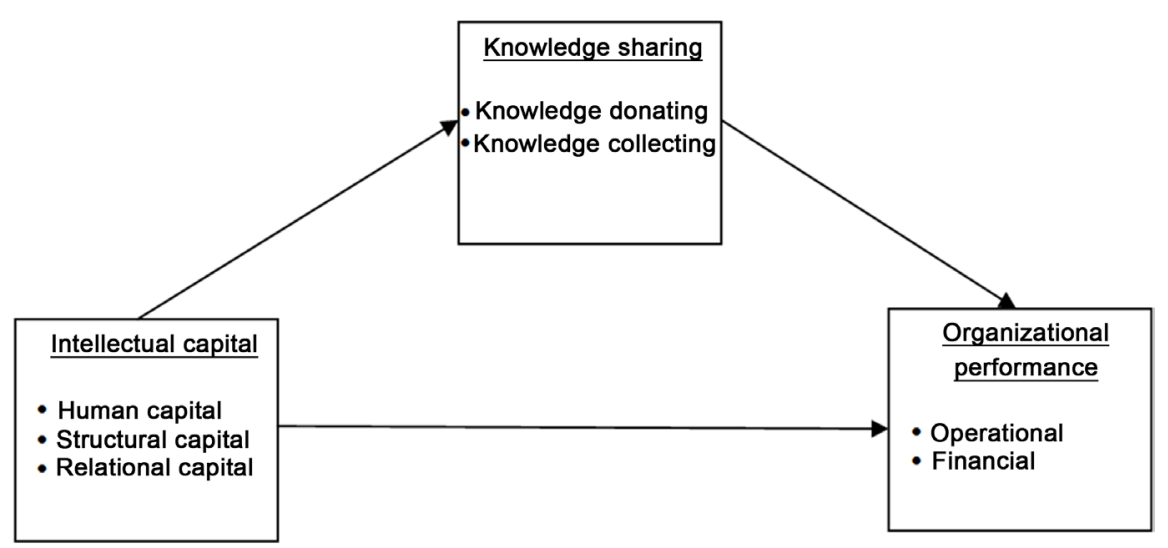

Figure 1. Research model. 
to share knowledge within the organization. It has also been reported that social capital, a dimension of intellectual capital, can influence knowledge sharing within organizations [141] and knowledge sharing between organizations [57]. In addition, [70] showed that knowledge sharing is highly influenced by a specific intellectual capital dimension, relational capital, compared to the other two dimensions, human capital and structural capital. Furthermore, [142] found that human capital as a dimension of intellectual capital influences knowledge acquisition and knowledge transfer the most.

H2. Intellectual capital positively affects knowledge sharing.

\subsubsection{Knowledge Sharing and Organizational Performance}

[35] found that KM practices, one of which relates to the ability to locate and share knowledge, have a direct relationship with organizational performance. The results of the study conducted by [33] showed that Knowledge Management Capabilities, which include knowledge learning and acquiring, knowledge sharing, and knowledge creating and improving, have a significant effect on organizational performance. [40] indicated that all factors of KM capabilities which are knowledge acquisition, knowledge sharing, and knowledge application have a positive and significant effect on the organizational performance of SME's. A study conducted in the hospitality industry by [37] showed that Knowledge Sharing (KS) was positively associated with organizational performance through the KS behaviors of Knowledge Collecting (KC) and Knowledge Donating (KD). [143] revealed that developing efficient mechanisms for creating, transferring, and integrating knowledge are necessary for organizations to achieve and maintain high levels of performance. [70] showed that organizational performance is positively influenced by Knowledge sharing.

H3. Knowledge sharing positively affects organizational performance.

H4. Knowledge sharing positively mediates the relationship between intellectual capital and organizational performance.

\section{Research Methodology}

\subsection{Survey}

The survey was designed by adopting readily-established constructs from the published literature. The items used to measure intellectual capital dimensions (human capital, structural capital and relational capital) were adopted from [71]. The items used to measure knowledge sharing dimensions (knowledge donating and knowledge collecting) were adopted from [28], and items used to measure organizational performance dimensions (operational performance and financial performance) were adopted from [76]. Respondents were asked to evaluate their agreement or disagreement with the statements provided using a 5-point Likert Scale where 5 indicated strong agreement and 1 indicated strong disagreement. The survey was initially prepared in English and then translated into Arabic language. Both English and Arabic versions were reviewed by four professors in Business Administration. Additionally, the Arabic version was pre-tested by five 
employees from different manufacturing companies. Necessary modifications were made as needed.

\subsection{Population and Sample}

The population for the research consisted of manufacturing companies in Amman, the capital of Jordan. The number of manufacturing companies located in Amman is 1200 [144]. The sample size appropriate for this population is 292 [145]. We decided to target one hundred companies using convince sampling. From each manufacturing company, five respondents were randomly selected. Therefore, a total of 500 questionnaires were distributed. Personal visits by the authors were made to the selected manufacturing companies. Data collection lasted for one and a half months. Selected manufacturing companies included electrical and electronics, machinery and mechanical appliances chemical, and pharmaceutical. Three hundred eighty three questionnaires were returned. Twenty seven questionnaires were defined as unusable and were excluded from subsequent analysis. The final number of usable questionnaires was 356 representing a response rate of $71.2 \%$. This response rate is relatively high compared with other studies in Jordan that used personal visits method such as [6] who received a response rate of $52 \%$.

\subsection{Validity and Reliability}

Face and content validity are important to ensure the appropriateness of the research instrument. This included a pilot study phase with four professors in Business Administration from the University of Jordan. In addition, five employees working in different manufacturing companies evaluated the appropriateness and relevance of the survey items. The question items were revised as needed. The content validity of the questionnaire was assured by broadly reviewing related empirical and theoretical studies related to the research constructs. Construct validity was assessed using Exploratory Factor Analysis with varimax rotation method [146]. The objective was to ensure that all items related to one construct loaded onto one factor with factor loadings greater than 0.40 and eigenvalue greater than 1 . Items that did not meet this criterion were deleted. To assure the appropriateness of the factor analysis, Kaiser-Meyer-Olkin (KMO) test for assessing sampling adequacy and Bartlett's test of sphericity to test for homogeneity of variances were applied for the measurement scales [146]. The results of KMO test showed that the statistics for all the scales were greater than 0.50, and Bartlett's test of sphericity revealed significant statistics for all the scales $(p<0.05)$ implying that factor analysis was appropriate. EFA was also performed for the overall constructs of intellectual capital, knowledge sharing and organizational performance. Table 1 and Table 2 show EFA results for the measurement scales.

The reliability of the study constructs was tested using Cronbach's $\alpha$-coefficient. All the constructs showed a reliability of $\alpha \geq 0.70$ implying a good reliability and internal consistency [146] [147]. Reliability tests were also performed for 
the overall constructs and the results also showed a reliability of $\alpha \geq 0.70$ for the three overall constructs. The mean values, standard deviations, and Cronbach's alpha values are reported in the Table 3.

\section{Results}

Regression analysis was applied to test study hypotheses. Normality of data is a prerequisite for regression analysis. We applied skewness and kurtosis tests to check the normality of the data [146]. The values for skewness ranged between -0.541 and -1.597 , while the values for kurtosis ranged between 0.111 and 1.434. Skewness and kurtosis values of \pm 2 from zero imply that data is normally distributed [148] [149] [150] indicating that normality was not a problem in our

Table 1. EFA for intellectual capital and organizational performance dimensions.

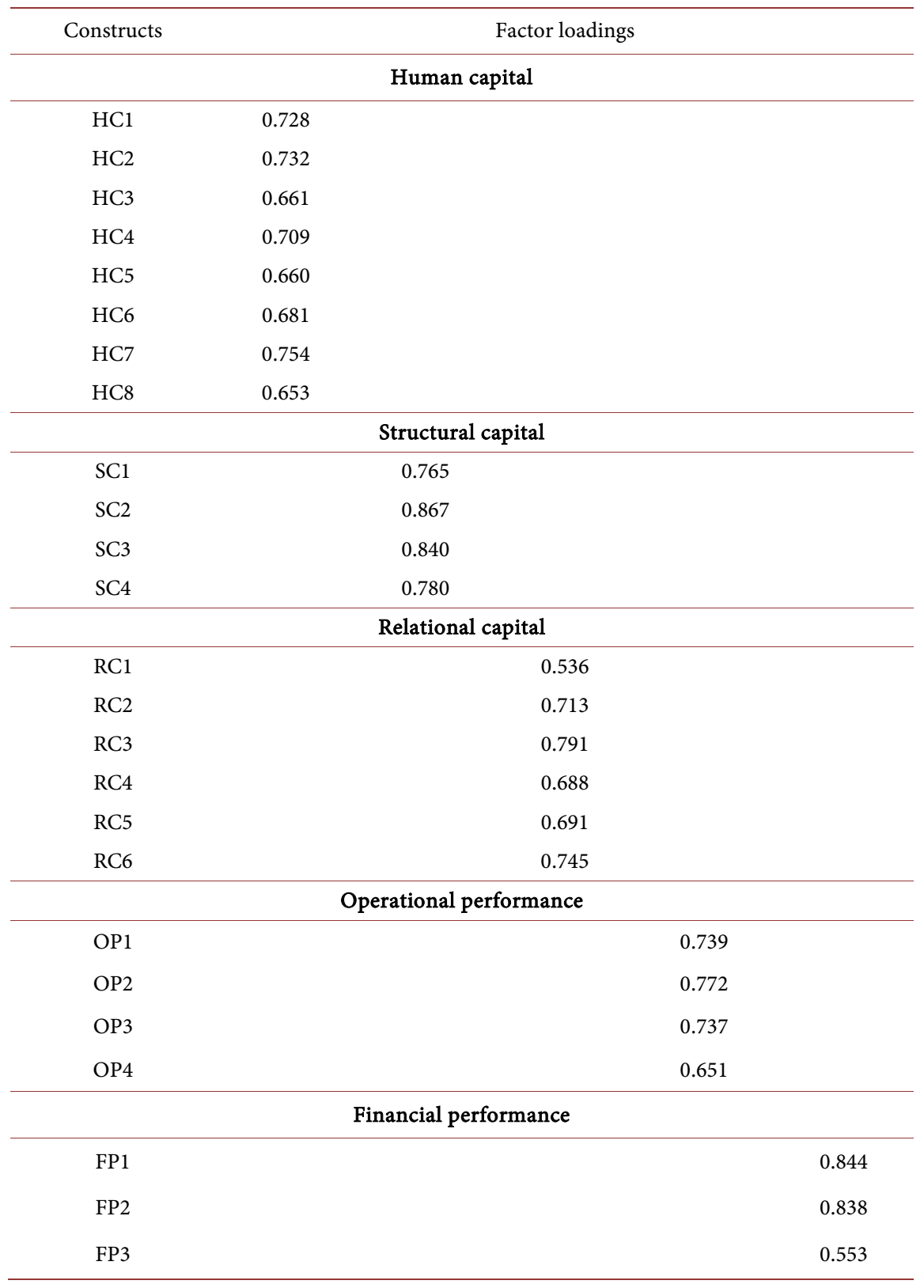


Table 2. EFA for knowledge sharing dimensions and overall scales.

\begin{tabular}{|c|c|c|c|c|c|}
\hline Constructs & \multicolumn{5}{|c|}{ Factor loadings } \\
\hline \multicolumn{6}{|c|}{ Knowledge donating } \\
\hline KD1 & 0.756 & & & & \\
\hline $\mathrm{KD} 2$ & 0.855 & & & & \\
\hline KD3 & 0.852 & & & & \\
\hline $\mathrm{KD} 4$ & 0.728 & & & & \\
\hline KD5 & 0.483 & & & & \\
\hline \multicolumn{6}{|c|}{ Knowledge collecting } \\
\hline $\mathrm{KC1}$ & & 0.699 & & & \\
\hline $\mathrm{KC} 2$ & & 0.797 & & & \\
\hline $\mathrm{KC} 3$ & & 0.858 & & & \\
\hline $\mathrm{KC} 4$ & & 0.770 & & & \\
\hline KC5 & & 0.684 & & & \\
\hline KC6 & & 0.644 & & & \\
\hline KC7 & & 0.499 & & & \\
\hline \multicolumn{6}{|c|}{ Intellectual capital } \\
\hline $\mathrm{HC}$ & & & 0.692 & & \\
\hline SC & & & 0.730 & & \\
\hline RC & & & 0.723 & & \\
\hline \multicolumn{6}{|c|}{ Knowledge sharing } \\
\hline $\mathrm{KD}$ & & & & 0.888 & \\
\hline KC & & & & 0.806 & \\
\hline \multicolumn{6}{|c|}{ Organizational performance } \\
\hline $\mathrm{OP}$ & & & & & 0.747 \\
\hline FP & & & & & 0.789 \\
\hline
\end{tabular}

Table 3. Means, standard deviations, and cronbach's $\alpha$-coefficient for the study constructs.

\begin{tabular}{cccc}
\hline Variable & Mean & Standard deviation & Cronbach's $\alpha$-coefficient \\
\hline Human Capital & 3.84 & 0.671 & 0.847 \\
Structural capital & 4.05 & 0.784 & 0.829 \\
Relational capital & 3.48 & 0.811 & 0.785 \\
Operational Performance & 3.85 & 0.727 & 0.700 \\
Financial performance & 3.78 & 0.770 & 0.716 \\
Knowledge Donating & 3.69 & 0.794 & 0.794 \\
Knowledge Collecting & 3.73 & 0.734 & 0.831 \\
Intellectual capital & 3.79 & 0.436 & 0.816 \\
Organizational performance & 3.82 & 0.536 & 0.713 \\
Knowledge sharing & 3.71 & 0.573 & 0.765 \\
\hline
\end{tabular}


research. Multicollinearity is a potential problem in regression models that may affect the results due to high correlation among the independent variables. Variance inflation factor (VIF) was performed to assess multicollinearity. As we use overall constructs in our analysis, we checked VIF for intellectual capital and knowledge sharing as independent variables with organizational performance as a dependent variable. The VIF value was 1.004. [151] suggested a cutoff value of 2.5 as a sign of multicollinearity; therefore, multicollinearity was not a concern in this research. To test the research hypotheses, we applied the procedure described by [1]. This approach requires conducting four separate regression analysis in order to identify the existence of a mediation effect.

In the first regression model, the independent variable should predict the dependent variable. In the second regression model, the independent variable should predict the mediator. In the third regression model, the mediator should predict the dependent variable. And finally, in the fourth regression model, both the independent variable and the mediator should be entered together to predict the dependent variable. If the effect of the independent variable on dependent variable while controlling for the mediator decreases to zero, then full mediation effect exists. In the first regression model, intellectual capital (the independent variable) was significantly related to organizational performance (the dependent variable) as shown in Table $4(\beta=0.493, p<0.001)$. Therefore hypothesis $\mathrm{H} 1$ was accepted. In the second regression model, intellectual capital (the independent variable) was significantly related to knowledge sharing (the mediator) providing support for hypothesis $\mathrm{H} 2(\beta=0.444, p<0.001)$. In the third regression model, knowledge sharing (the mediator) was significantly related to organizational performance (the dependent variable) providing support for hypothesis H3 $(\beta=0.449, p<0.001)$. In the fourth regression model, both intellectual capital and knowledge sharing (the independent variable and the mediator) were regressed together to predict organizational performance (the dependent variable). As shown in Table 4, the direct effect of intellectual capital on organiza-

Table 4. Regression analysis for mediation of the effect of intellectual capital on organizational performance through knowledge sharing.

\begin{tabular}{ccccc}
\hline Variables & $\begin{array}{c}\text { Step 1 } \\
\text { Organizational } \\
\text { performance }\end{array}$ & $\begin{array}{c}\text { Step 2 } \\
\text { Knowledge } \\
\text { sharing }\end{array}$ & $\begin{array}{c}\text { Step 3 } \\
\text { Organizational } \\
\text { performance }\end{array}$ & $\begin{array}{c}\text { Step } 4 \\
\text { Organizational } \\
\text { performance }\end{array}$ \\
\hline Constant) & $2.717^{* * *}$ & $2.308^{* * *}$ & $2.870^{* * *}$ & $2.240^{* * *}$ \\
Intellectual capital & $0.493^{* * *}$ & $0.444^{* * *}$ & $0.366^{* * *}$ \\
Knowledge sharing & 0.493 & 0.444 & 0.449 & $0.286^{* * *}$ \\
R & 0.243 & 0.197 & 0.201 & 0.556 \\
Adj. $\mathrm{R}^{2}$ & 0.241 & 0.194 & 0.199 & 0.309 \\
F-value & $89.733^{* * *}$ & $68.531^{* * *}$ & $70.375^{* * *}$ & $62.188^{* * *}$ \\
\hline
\end{tabular}

${ }^{* * *} p \leq 0.01$. 
tional performance in the first regression model $(\beta=0.493, p<0.001)$ was reduced in the fourth regression model, but still significant $(\beta=0.366, p<0.001)$ implying that only partial mediation effect may exist. To calculate the indirect effect according to [152], the regression coefficient obtained from regressing the mediator to predict the dependent variable $(\beta=0.449)$ should be multiplied by the regression coefficient obtained from regressing the independent variable to predict the mediator $(\beta=0.444)$. Thus, the indirect effect of intellectual capital on organizational performance through knowledge sharing $=0.449 * 0.444=$ 0.199. In order to ensure that the indirect effect is significant, it is recommended to run Sobel test [152]. The inputs for Sobel test are the unstandardized coefficient and the standard error of intellectual capital (the independent variable) on knowledge sharing (the mediator), and unstandardized coefficient and standard error of knowledge sharing (the mediator) on organizational performance (the dependent variable) when intellectual capital (the independent variable) is also a predictor of organizational performance. Sobel test showed that knowledge sharing significantly mediated the effect of intellectual capital on organizational performance ( $\mathrm{Z}=4.395, p<0.01$ ). Therefore, hypothesis $\mathrm{H} 4$ was accepted. Figure 2 and Figure 3 illustrate direct and indirect effects. Additionally, Table 5 provides summary of the tested hypotheses.

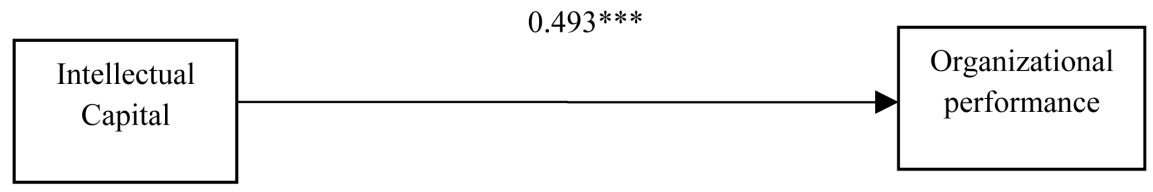

Figure 2. Intellectual capital-organizational performance model. Note: ${ }^{* *} p<0.001$.

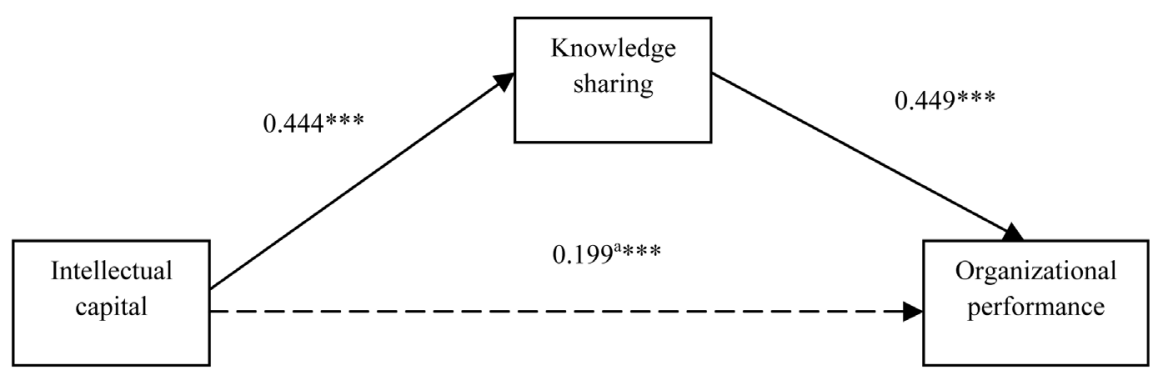

Figure 3. Intellectual capital-knowledge sharing-organizational performance model. Note: $p<0.001$; a: indirect effect.

Table 5. Summary of results.

\begin{tabular}{cccc}
\hline Hypothesis & Path & Effect & Result \\
\hline H1 & IC $\rightarrow$ OP & $0.493^{* * *}$ & Supported \\
H2 & IC $\rightarrow$ KS & $0.444^{* * *}$ & Supported \\
H3 & KS $\rightarrow$ OP & $0.449^{* * *}$ & Supported \\
H4 & IC $\rightarrow$ KS $\rightarrow$ OP & $0.199^{* * *}$ (indirect effect) & Supported \\
\hline
\end{tabular}

${ }^{* *} p \leq 0.01$. 


\section{Discussion and Conclusion}

\subsection{Discussion}

The purpose of this research is to examine the relationship between intellectual capital, knowledge sharing, and organizational performance in Jordanian manufacturing companies.

The results of this study proved that there is a significant positive effect of intellectual capital on organizational performance. This result supports the conclusions of [12] [66] [124] [136] [137]. Intellectual capital found to be of significance in respect of enhancing organizational performance and organizational profitability [138]. Intellectual capital can be developed and better utilized by adopting managerial practices and strategies that will create value through the organizations workforce, which will impact the organizational performance in the long run [153]. Therefore, organizations all over the globe are putting more efforts in investing not just in tangible assets but also in intangibles once as well.

However, not all studies undertaken to examine the relationship between intellectual capital and organizational performance have been favorable. For an example, [138] found that human capital has a significant negative relationship with firm performance. Moreover, [139] pointed out that there is no relationship between intellectual capital and firm performance. This can be explained by the fact that the relationship between intellectual capital and organizational performance is indirect suggesting that some variables exist that mediate or moderate the relationship. Another reason is that previous studies focused mainly on tangible assets with less attention placed on intangible assets and its impact on organizational performance.

This study has been found to prove a positive relation between intellectual capital and knowledge sharing in manufacturing companies which leads to increased levels of employee engagement therefore, enhancing the performance of the organization. This result is consistent with the findings of [57] [70] [140] [141] [142]. The finding indicates that intellectual capital components of human, structural, and relational capital lead to higher levels of knowledge sharing company wide. The knowledge created and accumulated from intellectual capital strategies should be shared and exchanged at all organizational levels to enhance and boost organizational benefits of applying intellectual capital strategy [69].

The result of this study proves the positive relationship between knowledge sharing and organizational performance. This result is consistent with the results of [33] [35] [37] [40] [70] [143]. Knowledge sharing, and the ability to obtain and apply knowledge are an essential skills that can contribute directly to the enhancement of the organizational performance. When employees share not just knowledge, but also all work related skills, and information, they can gain stronger capabilities to perform their job, therefore promoting the organizational performance, and gain competitive advantage over their rivals [37]. Other research indicated that the application and use of high-involvement human resource management practices can also contribute to organizational performance 
promotion [52].

The results of this study showed that knowledge sharing did actually mediate the relationship between intellectual capital and organizational performance in a significant way. This implies that manufacturing companies in Jordan deeply depend upon intellectual capital and knowledge sharing to enhance their organizational performance. Information sharing is a main determinant that enhances the performance benefits gained from intellectual capital. Companies neglecting knowledge sharing may not absorb the full benefits of intellectual capital. The real value of human capital, structural capital and relational capital can be realized by sharing the generated and acquired knowledge with different organizational functions and members. Managers have to remove all potential barriers to knowledge sharing and facilitate multi-functional cooperation and communication to achieve superior performance.

\subsection{Conclusion}

In conclusion, the purpose of this study was to study the relationship between intellectual capital, knowledge sharing, and organizational performance. A theoretical model was proposed and empirical testing was completed using a sample of 356 employees working at manufacturing companies in Jordan. The study concludes that intellectual capital is an essential enabler to knowledge sharing in Jordanian manufacturing companies. Additionally, the results demonstrated the important effect of intellectual capital on organizational performance. Moreover, the current study contributed to the existing literature by highlighting the key role of knowledge sharing in both enhancing organizational performance and positively mediating the relationship between intellectual capital and organizational performance.

\subsection{Limitations and Future Research}

The current study is subject for some limitation. Firstly, the examination of this study was conducted on one sector inside Jordan which would limit its results only to be confined with this sector alone. Therefore, we recommend that future researchers are to apply this study on different sectors to increase the credibility of the results. Secondly, longitudinal investigations can be undertaken to improve the reliability of the data collected and used in the research model. In addition, it might be possible that examining the main constructs in this study over a longer period would yield more insights into the associations between the research variables on organizational performance. Also, the scales used in this study for measuring variables may present some limitations, therefore we encourage that other researchers choose different scales to assure the credibility of results obtained. Finally, the study was conducted in Jordan therefore; data is applicable specifically to the Jordanian context.

Further studies can be conducted on the effect of intellectual capital on other performance measures such as employee creativity and innovation performance. Additionally, the effect of intellectual capital on the performance of service or- 
ganizations in Jordan is a worthy potential study. Moreover, the effects of contextual factors such as company size, company age, and industry type on the proposed relationships can be addressed in future studies. Furthermore, other mediating variables such as organizational commitment and employee satisfaction can be used in future studies in an attempt to better explain the relationship between intellectual capital and organizational performance.

\section{References}

[1] Baron, R.M. and Kenny, D.A. (1986) The Moderator-Mediator Variable Distinction in Social Psychological Research: Conceptual, Strategic, and Statistical Considerations. Journal of Personality and Social Psychology, 51, 1173-1182.

https://doi.org/10.1037/0022-3514.51.6.1173

[2] Shah, N. and Shah, S. (2010) Relationships between Employee Readiness for Organisational Change, Supervisor and Peer Relations and Demography. Journal of Enterprise Information Management, 23, 640-652.

https://doi.org/10.1108/17410391011083074

[3] Govaerts, N., Kyndt, E., Dochy, F. and Baert, H. (2011) Influence of Learning and Working Climate on the Retention of Talented Employees. Journal of Workplace Learning, 23, 35-55. https://doi.org/10.1108/13665621111097245

[4] Masa'deh, R. (2013) The Impact of Information Technology Infrastructure Flexibility on Firm Performance: An Empirical Study of Jordanian Public Shareholding Firms. Jordan Journal of Business Administration, 9, 204-224. https://doi.org/10.12816/0002054

[5] Masa'deh, R., Shannak, R., Maqableh, M. and Tarhini, A. (2016) The Impact of Knowledge Management on Job Performance in Higher Education: The Case of the University of Jordan. Journal of Enterprise Information Management, 29, 13-34.

[6] Obeidat, B., Masa'deh, R. and Abdallah, A. (2014) The Relationship among Human Resource Management Practices, Organizational Commitment, and Knowledge Management Processes: A Structural Equation Modeling Approach. International Journal of Business and Management, 9, 9-26. https://doi.org/10.5539/ijbm.v9n3p9

[7] Shannak, R., Masa'deh, R., Obeidat, B. and Almajali, D. (2010) Information Technology Investments: A Literature Review. Proceedings of the 14th IBIMA Conference on Global Business Transformation through Innovation and Knowledge Management: An Academic Perspective, Istanbul, Turkey, 23-24 June 2010, 13561368.

[8] Shannak, R., Masa'deh, R., Al-Zu’bi, Z., Obeidat, B., Alshurideh, M. and Altamony, H. (2012) A Theoretical Perspective on the Relationship between Knowledge Management Systems, Customer Knowledge Management, and Firm Competitive Advantage. European Journal of Social Sciences, 32, 520-532.

[9] Ho, L. (2008) What Affects Organizational Performance? Industrial Management \& Data Systems, 108, 1234-1254. https://doi.org/10.1108/02635570810914919

[10] OECD (2008) Intellectual Assets and Value Creation-Synthesis Report. OECD, Paris.

[11] Todericiu, R. and Serban, A. (2015) The Assessment of Intellectual Capital in Romanian Universities. Studies in Business and Economics, 10, 100-110. https://doi.org/10.1515/sbe-2015-0040

[12] Zeghal, D. and Maaloul, A. (2010) Analysing Value Added as an Indicator of Intellectual Capital and its Consequences on Company Performance. Journal of Intellectual Capital, 11, 39-60. https://doi.org/10.1108/14691931011013325 
[13] Kamukama, N., Ahiauzu, A. and Ntayi, J. (2010) Intellectual Capital and Performance: Testing Interaction Effects. Journal of Intellectual Capital, 11, 554-574. https://doi.org/10.1108/14691931011085687

[14] Zhou, A. and Fink, D. (2003) The Intellectual Capital Web: A Systematic Linking of Intellectual Capital and Knowledge Management. Journal of Intellectual Capital, 4, 34-48. https://doi.org/10.1108/14691930310455379

[15] Sharabati, A., Jawad, S. and Bontis, N. (2010) Intellectual Capital and Business Performance in the Pharmaceutical Sector of Jordan. Management Decision, 48, 105-131. https://doi.org/10.1108/00251741011014481

[16] Choudhury, J. (2010) Performance Impact of Intellectual Capital: A Study of Indian It Sector. International Journal of Business and Management, 5, 72-80. https://doi.org/10.5539/ijbm.v5n9p72

[17] Ariff, A.H., Islam, A. and van Zijl, T. (2016) Intellectual Capital and Market Performance: The Case of Multinational R\&D Firms in the US. The Journal of Developing Areas, 50, 487-495. https://doi.org/10.1353/jda.2016.0052

[18] Huang, C. and Liu, C. (2005) Exploration for the Relationship between Innovation, IT and Performance. Journal of Intellectual Capital, 6, 237-252. https://doi.org/10.1108/14691930510592825

[19] Kateb, G.A., Swies, R., Masa'deh, R. and Maqableh, M. (2014) An Investigation on the Critical Factors of Information System Implementation in Jordanian Information Technology Companies. European Journal of Business and Management, 7, 11-28.

[20] Nazari, J. and Herremans, I. (2007) Extended VAIC Model: Measuring Intellectual Capital Components. Journal of Intellectual Capital, 8, 595-609. https://doi.org/10.1108/14691930710830774

[21] Jardon, C. and Martos, M. (2009) Intellectual Capital and Performance in Wood Industries of Argentina. Journal of Intellectual Capital, 10, 600-616. https://doi.org/10.1108/14691930910996670

[22] Komnenic, B. and Pokrajcic, D. (2012) Intellectual Capital and Corporate Performance of MNCs in Serbia. Journal of Intellectual Capital, 13, 106-119. https://doi.org/10.1108/14691931211196231

[23] Vratskikh, I., Masa'deh, R., Al-Lozi, M. and Maqableh, M. (2016) The Impact of Emotional Intelligence on Job Performance via the Mediating Role of Job Satisfaction. International Journal of Business and Management, 11, 69-91. https://doi.org/10.5539/ijbm.v11n2p69

[24] Sherif, M. and Elsayed, M. (2016) The Impact of Intellectual Capital on Corporate Performance: Evidence from the Egyptian Insurance Market. International Journal of Innovation Management, 20, 1-47. https://doi.org/10.1142/S1363919616500341

[25] Alshurideh, M., Masa'deh, R. and Alkurdi, B. (2012) The Effect of Customer Satisfaction upon Customer Retention in the Jordanian Mobile Market: An Empirical Investigation. European Journal of Economics, Finance and Administrative Sciences, 47, 69-78.

[26] Chahal, H. and Bakshi, P. (2016) Measurement of Intellectual Capital in the Indian Banking Sector. The Journal of Decision Makers, 41, 61-73. https://doi.org/10.1177/0256090916629253

[27] Altamony, H., Masa'deh, R, Alshurideh, M. and Obeidat, B. (2012) Information Systems for Competitive Advantage: Implementation of an Organisational Strategic Management Process. Proceedings of the 18th IBIMA Conference on Innovation and Sustainable Economic Competitive Advantage: From Regional Development to World Economic, Istanbul, Turkey, 9-10 May 2011, 583-592. 
[28] Hooff, B. and Weenen, F. (2004) Committed to Share: Commitment and CMC Use as Antecedents of Knowledge Sharing. Knowledge and Process Management, 11, 13-24. https://doi.org/10.1002/kpm.187

[29] Kanaan, R., Masa'deh, R. and Gharaibeh, A. (2013) The Impact of Knowledge Sharing Enablers on Knowledge Sharing Capability: An Empirical Study on Jordanian Telecommunication Firms. European Scientific Journal, 9, 237-258.

[30] Shannak, R., Masa'deh, R. and Akour, M. (2012) Knowledge Management Strategy Building: Literature Review. European Scientific Journal, 8, 143-168.

[31] Asrar-ul-Haq, M. and Anwar, S. (2016) A Systematic Review of Knowledge Management and Knowledge Sharing: Trends, Issues, and Challenges. Cognet Business and Management, 3, 1-17. https://doi.org/10.1080/23311975.2015.1127744

[32] Ho, L. and Kuo, T. (2013) How System Quality and Incentive Affect Knowledge Sharing. Industrial Management \& Data Systems, 113, 1048-1063. https://doi.org/10.1108/IMDS-01-2013-0015

[33] Kuo, T. (2011) How to Improve Organizational Performance through Learning and Knowledge? International Journal of Manpower, 32, 581-603. https://doi.org/10.1108/01437721111158215

[34] Masa'deh, R., Obeidat, B. and Tarhini, A. (2016) A Jordanian Empirical Study of the Associations among Transformational Leadership, Transactional Leadership, Knowledge Sharing, Job Performance, and Firm Performance: A Structural Equation Modelling Approach. Journal of Management Development, 35, 681-705. https://doi.org/10.1108/JMD-09-2015-0134

[35] Zack, M., McKeen, J. and Singh, S. (2009) Knowledge Management and Organizational Performance: An Exploratory Analysis. Journal of Knowledge Management, 13, 392-409. https://doi.org/10.1108/13673270910997088

[36] Hajir, J.A., Obeidat, B.Y., Al-dalahmeh, M.A. and Masa'deh, R. (2015) The Role of Knowledge Management Infrastructure in Enhancing Innovation at Mobile Telecommunication Companies in Jordan. European Journal of Social Sciences, 50, 313330.

[37] Kim, T., Lee, G., Paek, S. and Lee, S. (2013) Social Capital, Knowledge Sharing and Organizational Performance. International Journal of Contemporary Hospitality, 25, 683-704. https://doi.org/10.1108/IJCHM-Jan-2012-0010

[38] Masa'deh, R., Obeidat, B., Zyod, D. and Gharaibeh, A. (2015) The Associations among Transformational Leadership, Transactional Leadership, Knowledge Sharing, Job Performance, and Firm Performance: A Theoretical Model. Journal of Social Sciences (COES\&RJ-JSS), 4, 848-866.

[39] Obeidat, B., El-Rimawi, S., Masa'deh, R., Maqableh, M. and Al-Jarrah, I. (2013) Evaluating the Profitability of the Islamic Banks in Jordan. European Journal of Economics, Finance and Administrative Sciences, 56, 27-36.

[40] Gharakhani, D. and Mousakhani, M. (2012) Knowledge Management Capabilities and SMEs' Organizational Performance. Journal of Chinese Entrepreneurship, 4, 35-49. https://doi.org/10.1108/17561391211200920

[41] Ho, L. (2011) Meditation, Learning, Organizational Innovation and Performance. Industrial Management \& Data Systems, 111, 113-131. https://doi.org/10.1108/02635571111099758

[42] Lin, H. (2007) Knowledge Sharing and Firm Innovation Capability: An Empirical Study. International Journal of Manpower, 28, 315-332.

https://doi.org/10.1108/01437720710755272

[43] Wendling, M., Oliveira, M. and Macada, A. (2013) Knowledge Sharing Barriers in 
Global Teams. Journal of Systems and Information Technology, 15, 239-253. https://doi.org/10.1108/JSIT-09-2012-0054

[44] Masa'deh, R., Gharaibeh, A., Maqableh, M. and Karajeh, H. (2013) An Empirical Study of Antecedents and Outcomes of Knowledge Sharing Capability in Jordanian Telecommunication Firms: A Structural Equation Modeling Approach. Life Science Journal, 10, 2284-2296.

[45] The, P. and Sun, H. (2012) Knowledge Sharing, Job Attitudes and Organisational Citizenship Behaviour. Industrial Management \& Data Systems, 112, 64-82. https://doi.org/10.1108/02635571211193644

[46] Abu-Jarad, I., Yusof, N. and Nikbin, D. (2010) A Review Paper on Organizational Culture and Organizational Performance. International Journal of Business and Social Science, 1, 26-46.

[47] Masa'deh, R., Tarhini, A., Al-Dmour, R. and Obeidat, B. (2015) Strategic IT-Business Alignment as Managers' Explorative and Exploitative Strategies. European Scientific Journal, 11, 450-470.

[48] Hao, Q., Kasper, H. and Muehlbacher, J. (2012) How Does Organizational Structure Influence Performance through Learning and Innovation in Austria and China. Chinese Management Studies, 6, 36-52. https://doi.org/10.1108/17506141211213717

[49] Ramayah, T., Samat, N. and Lo, M. (2011) Market Orientation, Service Quality and Organizational Performance in Service Organizations in Malaysia. Asia-Pacific Journal of Business Administration, 3, 8-27. https://doi.org/10.1108/17574321111116379

[50] Harris, C., McMahan, G. and Wright, P. (2012) Talent and Time Together. Personnel Review, 41, 408-427. https://doi.org/10.1108/00483481211229357

[51] Mills, A. and Smith, T. (2011) Knowledge Management and Organizational Performance: A Decomposed View. Journal of Knowledge Management, 15, 156-171. https://doi.org/10.1108/13673271111108756

[52] Moideenkutty, U., Al-Lamki, A. and Murthy, Y. (2011) HRM Practices and Organizational Performance in Oman. Personnel Review, 40, 239-251. https://doi.org/10.1108/00483481111106101

[53] Whelan, E. and Carcary, M. (2011) Integrating Talent and Knowledge Management: Where are the Benefits? Journal of Knowledge Management, 15, 675-687. https://doi.org/10.1108/13673271111152018

[54] Gan, K. and Saleh, Z. (2008) Intellectual Capital and Corporate Performance of Technology-Intensive Companies: Malaysia Evidence. Asian Journal of Business and Accounting, 1, 113-130.

[55] Bramhandkar, A., Erickson, S. and Applebee, I. (2007) Intellectual Capital and Organizational Performance: An Empirical Study of the Pharmaceutical Industry. Electronic Journal of Knowledge Management, 5, 357-362.

[56] Clarke, M., Seng, D. and Whiting, R. (2011) Intellectual Capital and Firm Performance in Australia. Journal of Intellectual Capital, 12, 505-530. https://doi.org/10.1108/14691931111181706

[57] Chen, M., Wang, Y. and Sun, V. (2012) Intellectual Capital and Organizational Commitment. Personnel Review, 41, 321-339. https://doi.org/10.1108/00483481211212968

[58] Brunold, J. and Durst, S. (2012) Intellectual Capital Risks and Job Rotation. Journal of Intellectual Capital, 13, 178-195. https://doi.org/10.1108/14691931211225021

[59] Stewart, T.A. and Stephanie, L. (1994) Your Company's Most Valuable Asset: Intellectual Capital. Fortune, 130, 68-74. 
[60] Edvinsson, L. and Malone, M.S. (1997) Intellectual Capital: Realizing Your Company's True Value by Finding Its Hidden Brainpower. Harper Business, New York.

[61] Stahle, P. and Hong, J. (2002) Dynamic Intellectual Capital in Global Rapidly Changing Industries. Journal of Knowledge Management, 6, 177-189. https://doi.org/10.1108/13673270210424693

[62] Youndt, M.A., Subramaniam, M. and Snell, S.A. (2004) Intellectual Capital Profiles: An Examination of Investment and Return. Journal of Management Studies, 41, 335-361. https://doi.org/10.1111/j.1467-6486.2004.00435.x

[63] Sofian, S., Tayles, M. and Pike, R. (2004) Intellectual Capital: An Evolutionary Change in Management Accounting Practices. Working Paper. http://www.datakala.com/files/Translation/DataKala_Tarjome_64.pdf

[64] Kamukama, N., Ahiauzu, A. and Ntayi, J. (2011) Competitive Advantage: Mediator of Intellectual Capital and Performance. Journal of Intellectual Capital, 12, 152-164. https://doi.org/10.1108/14691931111097953

[65] Sveiby, K.E. (1998) Measuring Intangibles and Intellectual Capital: An Emerging First Standard. http://www.sveiby.com.au/EmergingStandard.htm

[66] Bontis, N. (2000) Managing Organizational Knowledge by Diagnosing Intellectual Capital: Framing and Advancing the State of the Field. In: Bontis, N., Ed., World Congress on Intellectual Capital Readings, Butterworth-Heinemann, Boston, 621642.

[67] Chen, Y.S. (2008) The Positive Effect of Green Intellectual Capital on Competitive Advantages of Firms. Journal of Business Ethics, 77, 271-286.

https://doi.org/10.1007/s10551-006-9349-1

[68] Hsu, Y.H. and Fang, W. (2009) Intellectual Capital and New Product Development Performance: The Mediating Role of Organizational Learning Capability. Technological Forecasting and Social Change, 76, 664-677.

https://doi.org/10.1016/j.techfore.2008.03.012

[69] Shih K.H., Chang, C.J. and Lin, B. (2010) Assessing Knowledge Creation and Intellectual Capital in Banking Industry. Journal of Intellectual Capital, 11, 74-89. https://doi.org/10.1108/14691931011013343

[70] Ngah, R. and Ibrahim, A. (2011) The Influence of Intellectual Capital on Knowledge Sharing: Small and Medium Enterprises' Perspective. Communications of the IBIMA, 2011, Article ID: 444770. http://www.ibimapublishing.com/journals/CIBIMA/2011/444770/444770.pdf

[71] Kamukama, N. (2013) Intellectual Capital: Company's Invisible Source of Competitive Advantage. Competitiveness Review. An International Business Journal, 23, 260-283. https://doi.org/10.1108/10595421311319834

[72] Kong, E. (2010) Intellectual Capital and Non-Profit Organizations in the Knowledge Economy: Editorial and Introduction to Special Issue. Journal of Intellectual Capital, 11, 97-106. https://doi.org/10.1108/14691931011039624

[73] Santos-Rodrigues, H., Faria, J., Cranfield, D. and Morais, C. (2013) Intellectual Capital and Innovation: A Case Study of a Public Healthcare Organisation in Europe. Electronic Journal of Knowledge Management, 11, 361-372.

[74] De Pablos, P. (2003) Intellectual Capital Reporting in Spain: A Comparative View. Journal of Intellectual Capital, 4, 61-81. https://doi.org/10.1108/14691930310455397

[75] Kianto, A., Hurmelinna-Laukkanen, P. and Ritala, P. (2010) Intellectual Capital in Service- and Product-Oriented Companies. Journal of Intellectual Capital, 11, 305 325. https://doi.org/10.1108/14691931011064563

[76] Wang, Z., Wang, N. and Liang, H. (2014) Knowledge Sharing, Intellectual Capital 
and Firm Performance. Management Decision, 52, 230-258. https://doi.org/10.1108/MD-02-2013-0064

[77] Tarus, D. and Sitienei, E. (2015) Intellectual Capital and Innovativeness in Software Development Firms: The Moderating Role of Firm Size. Journal of African Business, 16, 48-65. https://doi.org/10.1080/15228916.2015.1061284

[78] Hussi, T. (2004) Reconfiguring Knowledge Management-Combining Intellectual Capital, Intangible Assets and Knowledge Creation. Journal of Knowledge Management, 8, 36-52. https://doi.org/10.1108/13673270410529091

[79] Mention, A. and Bontis, N. (2013) Intellectual Capital and Performance within the Banking Sector of Luxembourg and Belgium. Journal of Intellectual Capital, 14, 286-309. https://doi.org/10.1108/14691931311323896

[80] Abadulai, M.S., Kwon, Y. and Moon, J. (2012) Intellectual Capital and Firm Performance: An Empirical Study of Software Firms in West Africa. African Journal of Information System, 4, 23-36.

[81] Joshi, M., Cahill, D., Sidhu, J. and Kansal, M. (2013) Intellectual Capital and Financial Performance: An Evaluation of the Australian Financial Sector. Journal of Intellectual Capita, 14, 264-285. https://doi.org/10.1108/14691931311323887

[82] Zambon, S. (2002) Accounting, Intangible and Intellectual Capital: An Overview of the Issues and some Considerations. Working Paper 4, University of Ferrara, Ferrara.

[83] Toth, Z. and Jonas, T. (2012) Measuring Intellectual Capital in the Light of the EFQM Excellence Model: Evidence from Hungary. International Journal of Quality and Service Sciences, 4, 316-331. https://doi.org/10.1108/17566691211288313

[84] Mondal, A. and Ghosh, S. (2012) Intellectual Capital and Financial Performance of Indian Banks. Journal of Intellectual Capital, 13, 515-530. https://doi.org/10.1108/14691931211276115

[85] Pearse, N. (2009) The Role of Experiences in Creating and Developing Intellectual Capital. Management Research News, 32, 371-382. https://doi.org/10.1108/01409170910944317

[86] Bimpitsos, C. and Petridou, E. (2012) A Transdisciplinary Approach to Training: Preliminary Research Findings Based on a Case Analysis. European Journal of Training and Development, 36, 911-929. https://doi.org/10.1108/03090591211280964

[87] Jelenic, D. (2011) The Importance of Knowledge Management in OrganizationsWith Emphasis on the Balanced Scorecard Learning and Growth Perspective. Paper presented at Management, Knowledge and Learning International Conference, Celje, Slovenia, 22-24 June 2011, 33-43.

[88] Akhavan, P., Rahimi, A. and Mehralian, G. (2013) Developing a Model for Knowledge Sharing in Research Centers. VINE: The Journal of Information and Knowledge Management Systems, 43, 357-393. https://doi.org/10.1108/VINE-06-2012-0020

[89] Chiang, H., Han, T. and Chuang, J. (2011) The Relationship between High-Commitment HRM and Knowledge-Sharing Behavior and Its Mediators. International Journal of Manpower, 32, 604-622. https://doi.org/10.1108/01437721111158224

[90] Fong, P. and Choi, S. (2009) The Processes of Knowledge Management in Professional Services Firms in the Construction Industry: A Critical Assessment of Both Theory and Practice. Journal of Knowledge Management, 13, 110-126. https://doi.org/10.1108/13673270910942736 
[91] Masa'deh, R. and Shannak, R. (2012) Intermediary Effects of Knowledge Management Strategy and Learning Orientation on Strategic Alignment and Firm Performance. Research Journal of International Studies, 24, 112-128.

[92] Obeidat, B., Al-Suradi, M., Masa'deh, R. and Tarhini, A. (2016) The Impact of Knowledge Management on Innovation: An Empirical Study on Jordanian Consultancy Firms. Management Research Review, 39, 1214-1238. https://doi.org/10.1108/mrr-09-2015-0214

[93] Jimenez-Jimenez, D. and Sanz-Valle, R. (2013) Studying the Effect of HRM Practices on the Knowledge Management Process. Personnel Review, 42, 28-49. https://doi.org/10.1108/00483481311285219

[94] Masa'deh, R., Obeidat, B., Al-Dmour, R. and Tarhini, A. (2015) Knowledge Management Strategies as Intermediary Variables between IT-Business Strategic Alignment and Firm Performance. European Scientific Journal, 11, 344-368.

[95] Ma, Z., Qi, L. and Wang, K. (2008) Knowledge Sharing in Chinese Construction Project Teams and Its Affecting Factors: An Empirical Study. Chinese Management Studies, 2, 97-108. https://doi.org/10.1108/17506140810882234

[96] Fong, C., Ooi, K., Tan, B., Lee, V. and Chong, A.Y. (2011) HRM Practices and Knowledge Sharing: An Empirical Study. International Journal of Manpower, 32, 704-723. https://doi.org/10.1108/01437721111158288

[97] Nonaka, I. and Takeuchi, H. (1995) The Knowledge-Creating Company: How Japanese Companies Create the Dynamics of Innovation. Oxford University Press, New York.

[98] Lai, W. (2013) Interoperability of Implicit and Explicit Firm-Level Knowledge Accumulation. Journal of Strategy and Management, 6, 229-241. https://doi.org/10.1108/JSMA-08-2012-0042

[99] Ringel-Bickelmaier, C. and Ringel, M. (2010) Knowledge Management in International Organisations. Journal of Knowledge Management, 14, 524-539. https://doi.org/10.1108/13673271011059509

[100] Cao, Y. and Xiang, Y. (2012) The Impact of Knowledge Governance on Knowledge Sharing. Management Decision, 50, 591-610. https://doi.org/10.1108/00251741211220147

[101] Cyr, S. and Choo, C.W. (2010) The Individual and Social Dynamics of Knowledge Sharing: An Exploratory Study. Journal of Documentation, 66, 824-846. https://doi.org/10.1108/00220411011087832

[102] Masa'deh, R., Gharibeh, A., Tarhini, A. and Obeidat, B. (2015) Knowledge Sharing Capability: A Literature Review. Proceedings of the 4th Scientific and Research Conference on New Trends in Business, Management, and Social Sciences, Istanbul, Turkey, 19-20 September 2015, 1-16. https://doi.org/10.2139/ssrn.2696924

[103] Ling, T.N., San, L.Y. and Hock, N.T. (2009) Trust: Facilitator of Knowledge-Sharing Culture. Communications of the IBIMA, 7, 137-142.

[104] Tohidinia, Z. and Mosakhani, M. (2010) Knowledge Sharing Behavior and Its Predictors. Industrial Management \& Data Systems, 110, 611-631. https://doi.org/10.1108/02635571011039052

[105] Marouf, L.N. (2007) Social Networks and Knowledge Sharing in Organizations: A Case Study. Journal of Knowledge Management, 11, 110-125. https://doi.org/10.1108/13673270710832208

[106] Burke, M.E. (2011) Knowledge Sharing in Emerging Economies. Library Review, 60, 5-14. https://doi.org/10.1108/00242531111100531

[107] Chow, W.S. and Chan, L.S. (2008) Social Network, Social Trust and Shared Goals in 
Organizational Knowledge Sharing. Information \& Management, 45, 458-465. https://doi.org/10.1016/j.im.2008.06.007

[108] Casimir, G., Lee, K. and Loon, M. (2012) Knowledge Sharing: Influences of Trust, Commitment and Cost. Journal of Knowledge Management, 16, 740-753. https://doi.org/10.1108/13673271211262781

[109] Zboralski, K. (2009) Antecedents of Knowledge Sharing in Communities of Practice. Journal of Knowledge Management, 13, 90-101. https://doi.org/10.1108/13673270910962897

[110] Fathi, N.M., Eze, U.C. and Goh, G.G.G. (2011) Key Determinants of Knowledge Sharing in an Electronics Manufacturing Firm in Malaysia. Library Review, 60, 53-67. https://doi.org/10.1108/00242531111100577

[111] Van der Rijt, P.G.A. (2002) Precious Knowledge. Amsterdam: The Amsterdam School of Communications Research.

[112] Weggeman, M. (2000) Kennismanagement: De praktijk [Knowledge Management: Practice]. Scriptum Management, Schiedam, Netherlands.

[113] Oldenkamp, J.H. (2001) Succesvol Overdragen van Kennis [Successful Knowledge Transfer]. Lemma BV, Utrecht, Netherlands.

[114] De Vries, R., Hooff, B. and De Ridder, J. (2006) Explaining Knowledge Sharing: The Role of Team Communication Styles, Job Satisfaction, and Performance Beliefs. Communication Research, 33, 115-135. https://doi.org/10.1177/0093650205285366

[115] Sawal, M., Azmi, N., Idris, A., Alhady, S., Noordin, N. and Zakaria, Z. (2012) Knowledge Sharing Behaviors and Individual Factors towards Online Socialization. http://www.ipedr.com/vol28/25-ICEMM2012-T10010.pdf

[116] Kamasak, R. and Bulutlar, F. (2010) The Influence of Knowledge Sharing on Innovation. European Business Review, 22, 306-317. https://doi.org/10.1108/09555341011040994

[117] Dysvik, A., Buch, R. and Kuvaas, B. (2013) Knowledge Donating and Knowledge Collecting: The Moderating Roles of Social and Economic LMX. Leadership \& Organization Development Journal, 36, 35-53. https://www.researchgate.net/publication/258031973_Knowledge_donating_and_k nowledge_collecting_The_moderating_roles_of_social_and_economic_LMX

[118] Alhady, S., Sawal, M., Idris, A., Azmi, A. and Zakaria, Z. (2011) Knowledge Sharing Behavior and Individual Factors: A Relationship Study in the I-Class Environment. http://www.ipedr.com/vol6/27-A10022.pdf

[119] Uzkurt, C., Kumar, R., Kimzan, H. and Eminoglu, G. (2013) Role of Innovation in the Relationship between Organizational Culture and Firm Performance. European Journal of Innovation Management, 16, 92-117. https://doi.org/10.1108/14601061311292878

[120] Agbejule, A. (2011) Organizational Culture and Performance: The Role of Management Accounting System. Journal of Applied Accounting Research, 12, 74-89. https://doi.org/10.1108/09675421111130621

[121] Tuanmat, T. and Smith, M. (2011) Changes in Management Accounting Practices in Malaysia. Asian Review of Accounting, 19, 221-242. https://doi.org/10.1108/13217341111185146

[122] Molina, C. and Callahan, J. (2009) Fostering Organizational Performance. Journal of European Industrial Training, 33, 388-400. https://doi.org/10.1108/03090590910966553

[123] Bhatti, W., Waris, S., Zaheer, A. and Rehman, K. (2011) The Effect of Commitment and Motivation on Human Talent and Its Contribution to Organizational Perfor- 
mance. Management \& Marketing Challenges for the Knowledge Society, 6, 471482.

[124] Tseng, S. (2010) The Correlation between Organizational Culture and Knowledge Conversion on Corporate Performance. Journal of Knowledge Management, 14, 269-284. https://doi.org/10.1108/13673271011032409

[125] Slack, N., Chambers, S. and Johnston, R. (2004) Operations Management. 4th Edition, Pearson Education, Harlow.

[126] Santa, R., Ferrer, M., Bretherton, P. and Hyland, P. (2010) Contribution of CrossFunctional Teams to the Improvement in Operational Performance. Team Performance Management, 16, 148-168. https://doi.org/10.1108/13527591011053241

[127] Feng, M., Terziovski, M. and Samson, D. (2008) Relationship of ISO 9001:2000 Quality System Certification with Operational and Business Performance. Journal of Manufacturing Technology Management, 19, 22-37. https://doi.org/10.1108/17410380810843435

[128] Manikas, I. and Terry, L. (2010) A Case Study Assessment of the Operational Performance of a Multiple Fresh Produce Distribution Centre in the UK. British Food Journal, 112, 653-667.

[129] Luo, Y., Huang, Y. and Wang, S. (2012) Guanxi and Organizational Performance: A Meta-Analysis. Management and Organization Review, 8, 139-172. https://doi.org/10.1111/j.1740-8784.2011.00273.x

[130] Peng, D.X., Schroeder, R.G. and Shah, R. (2011) Competitive Priorities, Plant Improvement and Innovation Capabilities, and Operational Performance: A Test of Two Forms of Fit. International Journal of Operations \& Production Management, 31, 484-510. https://doi.org/10.1108/01443571111126292

[131] Fullerton, R. and Wempe, W. (2009) Lean Manufacturing, Non-Financial Performance Measures, and Financial Performance. International Journal of Operations \& Production Management, 29, 214-240. https://doi.org/10.1108/01443570910938970

[132] Chang, C. and Lee, Y. (2012) Verification of the Influences of Intellectual Capital upon Organizational Performance of Taiwan-listed Info-Electronics Companies with Capital Structure as the Moderator. The Journal of International Management Studies, 7, 80-92.

[133] Hernaus, T., Bach, M. and Vuksic, V. (2012) Influence of Strategic Approach to BPM on Financial and Non-Financial Performance. Baltic Journal of Management, 7, 376-396. https://doi.org/10.1108/17465261211272148

[134] Katchova, A. and Enlow, S. (2013) Financial Performance of Publicly-Traded Agribusinesses. Agricultural Finance Review, 73, 58-73. https://doi.org/10.1108/00021461311321311

[135] Gruian, C. (2011) The Influence of Intellectual Capital on Romanian Companies' Financial Performance. Annales Universitatis Apulensis Series Oeconomica, 13, 260-272.

[136] Kujansivu, P. and Lonnqvist, A. (2008) Measuring the Impacts of an IC Development Service: The Case of the Pietari Business Campus. Electronic Journal of Knowledge Management, 7, 469-480.

[137] Vishnu, S. and Gupta, K. (2014) Intellectual Capital and Performance of Pharmaceutical Firms in India. Journal of Intellectual Capital, 15, 83-99. https://doi.org/10.1108/JIC-04-2013-0049

[138] Firer, S. and Stainbank, L. (2003) Testing the Relationship between Intellectual Capital and a Company's Performance: Evidence from South Africa. Meditari Accountancy Research, 11, 25-44. https://doi.org/10.1108/10222529200300003 
[139] Kamath, G.B. (2008) Intellectual Capital and Corporate Performance in Indian Pharmaceutical Industry. Journal of Intellectual Capital, 9, 684-704. https://doi.org/10.1108/14691930810913221

[140] Ruta, C.D. and Macchitella, U. (2008) Fostering Intellectual Capital through Communication Technologies: An Analysis of Knowledge Sharing Determinants. International Journal of Learning and Intellectual Capital, 5, 123-152. https://doi.org/10.1504/IJLIC.2008.020148

[141] Nahapiet, J. and Ghoshal, S. (1998) Social Capital, Intellectual Capital, and the Organizational Advantage. The Academy of Management Review, 23, 242-266.

[142] Seleim, A. and Khalil, O. (2011) Understanding the Knowledge Management-Intellectual Captial Relationship: A Two-Way Analysis. Journal of Intellectual Capital, 12, 286-614. https://doi.org/10.1108/14691931111181742

[143] Yeo, R.K. (2006) Building Knowledge through Action Systems, Process Leadership and Organizational Learning. Foresight, 8, 34-44. https://doi.org/10.1108/14636680610682021

[144] Amman Chamber of Industry (ACI) (2015). http://www.aci.org.jo/development/ar/index.php

[145] Sekaran, U. and Bougie, R. (2013) Research Methods for Business. 6th Edition, John Wiley \& Sons Ltd., UK.

[146] Hair, G., Black, B., Babin, B., Anderson, R. and Tatham, R. (2010) Multivariate Data Analysis. 7th Edition, Pearson, Upper Saddle River, New Jersey.

[147] Nunnally, J. (1978) Psychometric Theory. 2nd Edition, McGraw-Hill, New York.

[148] Field, A. (2009) Discovering Statistics using SPSS. SAGE, London.

[149] Gravetter, F. and Wallnau, L. (2014) Essentials of Statistics for the Behavioral Sciences. 8th Edition, Wadsworth, Belmont, CA.

[150] Trochim, W.M. and Donnelly, J.P. (2006) The Research Methods Knowledge Base. 3rd Edition, Atomic Dog, Cincinnati, $\mathrm{OH}$.

[151] Allison, P.D. (1999) Multiple Regression: A Primer. Pine Forge Press, Thousand Oaks, CA.

[152] Sobel, M.E. (1982) Asymptotic Confidence Intervals for Indirect Effects in Structural Equation Models. Sociological Methodology, 13, 290-321. https://doi.org/10.2307/270723

[153] Schiuma, G. and Lerro, A. (2008) Intellectual Capital and Company's Performance Improvement. Measuring Business Excellence, 12, 3-9.

https://doi.org/10.1108/13683040810881153 
Submit or recommend next manuscript to SCIRP and we will provide best service for you:

Accepting pre-submission inquiries through Email, Facebook, LinkedIn, Twitter, etc. A wide selection of journals (inclusive of 9 subjects, more than 200 journals)

Providing 24-hour high-quality service

User-friendly online submission system

Fair and swift peer-review system

Efficient typesetting and proofreading procedure

Display of the result of downloads and visits, as well as the number of cited articles Maximum dissemination of your research work

Submit your manuscript at: http://papersubmission.scirp.org/

Or contact cn@scirp.org 